\title{
School Plant Facility and Maintenance: A Necessity Effective Teaching and Learning in Technical Vocational Education and Training
}

\author{
Jane Itohan Oviawe ${ }^{1}$, David $\mathrm{OMOH}^{2}$ \& Uwameiye, $\mathrm{R}^{3}$ \\ 1,3Department of Vocational and Technical Education, Ambrose Ali University, Ekpoma-Edo State \\ ${ }^{2}$ Department of Geoscience, University of Lagos, Akoka-Yaba, Lagos \\ janeoviawe98@gmail.com,domoh95@yahoo.com,uwaray56@yahoo.com
}

\begin{abstract}
Since Technical Vocational Education and Training (TVET) is all about skill acquisition in order to prepare learners to fit into the world of work and become self- reliant, the curriculum for such training has to involve the use of adequate provision of necessary facilities called school plant in order to achieve effective teaching and learning. The purpose of this paper is to affirm the need for adequate facilities in a Technical and Vocational Institution, and the necessity to have a good maintenance structure in place in order to achieve the desired objectives and enhance the life span of the facilities. This paper also looked a tissue of challenges facing the maintenance of these facilities in Technical and Vocational Educational institutions in Nigeria. Conclusions were made looking at suggestions in order to achieve adequacy in the provisions of facilities such as machines, workshops, equipment and tools in Technical and Vocational schools which can effectively enhance teaching and learning and by extension provide economic growth in any nation.
\end{abstract}

Keywords: Technical Vocational Education and Training, Teaching and Learning, School Plant Facilities, and Maintenance.

\section{Introduction}

Education is an important mechanism useful for the growth and development of any country. This assertion has been proven beyond doubt when we look at the roles played by people who are educated in developing major areas in the sciences, social, economic and political structure which in turn has improved the lives of many individuals and households and hence, providing a conducive environment to live in. Aloga (2014) stated that because of these e d u cational values, te $\mathrm{chn}$ ical education need to be able to prepare individuals in the $21^{\text {st }}$ century to effectively function. However, it is unfortunate that Technical and Vocational schools in Nigerian are ready at least to handle new practices and rapid rise in information in the area technical education which keeps improving on a day to day basis because of challenges of inadequate funding to develop infrastructure and those that result from teachers industrial actions, lack of machines and equipment, and even lack of a well - equipped workshops especially in Technical and Vocational Educational institutions. Audu, Kamin and Balash (2013) posited that the primary aim of all TVET program is to acquire aptitudes for gainful employment and skills needed to be employable in a specified area or occupation, it can either be paid or self-employment. Developing a link between employment (paid or self) and TVET forms the basis of the optimal approach and practice perceived throughout the world.

One aspect that is most significant in TVET tended towards acquisition of employable skills in order for the learners to be ready for the world of work, hence teaching delivery systems ought to be in a conducive, place for developing the skills of the work force to improve their economic situation and create employment for the youths. Technical vocational education and training (TVET) is used as a comprehensive term that refers specific educational process that involve understanding and knowledge that relates to occupations in different sectors of social and economic life, acquiring practical skills, studying of technology and related sciences and general education. It can be referred to further as: (i) a technique that assist in alleviating poverty; (ii) a tool to promote environmental and sustainable development; (iii) aspect of life-long learning and preparation to be responsible citizens; (iv), means of preparing for jobs and effectiveness in the work place; and (v) a means of facilitating poverty alleviation (UNESCO \& ILO, 2007). The Federal Republic of Nigeria (FRN) (2013) defined Technical and vocational education and training as facet of education geared towards skill acquisition in addition to the basic knowledge. Maclean and Wilson (2009) defined TVET as a planned program of courses and learning experiences that begins with exploration of career options, supports basic academic and life skills, and enables achievement of high academic standards, leadership, preparation for industry-defined work, and advanced and continuing education. 
Hence, Enyekit and Enyenili (2007) stated that although technical and training involves a teaching and learning process, it also assist learners in preparing for employment that require specialized knowledge that, is needed by society which can be best carried out in schools. It is concerned with a series of jobs that require specialized personnel whose preparation is short. It includes within the labor force a spectrum of professional and semi-skilled professionals. The TVET is unique in that the environment needed for the program to be effective is one where the student can imagine, create, design, repair, disassemble, construct, test and experiment is a necessary provision (Ezeji, 1998). This implies that workshop which is active is fundamental to the study of TVET programs since TVET is a mechanism where the workforce skills, its effective provision can only be made possible with a well-equipped school plant and facilities.

\section{The Concept of School Plant and Facilities in TVET}

The school plant consist of all facilities put in place in the Technical and Vocational school environment in order to enhance teaching and learning process and to achieve the desired objectives. Ezeji (1998) defined facilities as it relates to TVET, to include the tools, machines and supplies which stimulate an industrial environment in an education setting. Facilities include the physical plan (workshop building), equipment selection and organization. School plan as defined by Aloga (2014), is "the site, building, equipment and all the facilities within the school which enhance the teaching and learning activities and at the same time protects the physical well-being of the teachers and learners from rain, sunshine and other environmental hazards". Olaitan (1998) stated that the school plants can be seen to be made up of basic structures and systems that a technical and vocational institution or school needs to effectively function and accomplish the goal for which it was established. This paper however, defines school plant and facilities as the totality of all the requirements required to mount and run any TVET program. These include the workshop/laboratories buildings, tools and equipment, machines, personnel and the systems devised to facilitate a smooth, efficient and effective use of the buildings; tools and equipment; as well as personnel to set up the stage for learning.

Olaitan (1998) added that school plants and facilities include: water supply infrastructures (tanks, deep well water, borehole, pipe borne water); electrical infrastructure (generator, overhead electrical conductor lines, air conditioners, fans, electrical fittings); library (magazines, journals, stationary, textbooks); secretarial machines (vehicles and computers); (staff furniture, classroom/office); equipment (machines/tools workshop, laboratory/workshop); building (equipment, office blocks, assembly halls, staff quarters, hostels, workshops, laboratories, libraries and classroom blocks). Similarly, Aloga (2014) stated that for effective teaching and learning situation, school building and educational goals, should be viewed as being interwoven, for example school library should be seen as a learning laboratory par excellence where learners find the world of knowledge, interact directly with resources, acquire information and develop research skill for lifelong learning, hence it represents the totality and message of the entire environment for realizing school goals and objectives. Khan (2016) listed the school plant facilities relevant to effective teaching and learning in TVET to include: a well-ventilated and quality lighted students classroom, subject room, school library, staff room, staff common room, Principal/Head of school office, student laboratory, school workshop, tools, equipment, maintenance office, students hostel, generator room, toilet/bathroom, reading room, car parking area, school hall, school bus, student playground, health centre, student cafeteria.

But Knerzervich (1975) emphasized that school plant is an essential part of the school facilities by reiterating that it is the avenue to interpret what has been learnt theoretically. In constructing and arranging helps the school curriculum physically express the theories. This provides an environment to improve the learning and teaching process as well as protect the occupant's physical wellbeing. Knerzervich added that learning and teaching doesn't just happen by itself, school facilities provide meaning to planned curriculum and extracurricular activities. The nature and types of the educational program to be offered in any technical and vocational institution will also ascertain the type and nature of the school plant to be devised. In Olaitan (1998) stated that students and teachers both need a place to record, experiment, think, listen, view, interact, confer, write, read and search, hence a school plant becomes inevitable; more so, that student also need place to conduct the affairs of students or social gatherings while teachers need require facilities to prepare teachers presentation, diagnose student needs, conference room for team planning and office space. Unruh further added that new innovations in the learning-teaching process moves beyond reading towards how to 
involve students in the application, evaluating, synthesizing and analyzing knowledge gained, stressing the need for a flexible space in the school.

Relevance of School Plant: TVET emphasizes the acquisition of skills for useful and gainful employment and eradication of poverty. In this realization FRN (2013) articulated the objectives of TVET as follows: (i) provide training and improve the skills of individuals to be economically self-reliant; (ii) to instill vocational skills and technical knowledge needed for economic and agricultural development; and (iii) to provide trained manpower in the applied sciences technology and business particularly at craft, advanced craft and technical levels. The dynamic nature of the social and academic environment required the school plant should be designed with emphasis on flexibility. Towards the realization of these laudable objectives of TVET, Uzodimma (1996) posited that the following should be ensured:

- Conditions of instruction should compare favorable with desirable conditions in the occupations concerned;

- Real jobs should provide the laboratory for vocational education;

- Instructions should be available to those who need, want and can profit by it;

- TVET instructions should be based on occupational needs;

- Standards should be as high as or higher than those in the occupations concerned;

- Equipment and environment should be the exact replica of the industry; and

- Instructional programs should be characterized by flexibility.

Emphasizing the relevance of school plant and facilities in Ezeji (1998) asserted that the learning process of students is greatly enhanced where there is an environment they can actively explore. They added that school plant and facilities are significant to activities in the community such as conference, sports, meetings, youth clubs, home economic centres, adult education and extra-moral classes, hence, school plant and its environment is vital in achieving educational goals. Olaitan (1998) stated that school curriculum should be linked to educational facilities, given the point that school plant helps to interpret the school curriculum. It was stated further that the school programs conveyed via the school design, arrangement, playgrounds, building and site and also that designing a well-functioning school building with a wide range of teaching materials and tools provide efficient delivery of the school curriculum and impact positively on academic performance.

\section{Facilities in TVET Institutions in Nigeria}

To ease professional training that will lead to the acquisition of practical skills, knowledge as well as attitude relevant to the needs of the world of work, requires the provision of instructional facilities. To this end, in Nwachukwu (2012) stressed that there is definite need for provision of adequate facilities in every technical and vocational institutions since they are designed to serve specific purposes in the teaching and learning processes. This is because without these facilities the learners may not be able to experiment, test, construct, disassemble, repair, design, create, imagine and study. Stated that school plants and facilities are employed to explain theories and offer first hand opportunity for experiences; develop scientific aptitudes and skills; for inquiry and observation; to offer diversity in thoughts; for scientific discovery and investigation; and for demonstration and experimentation. School plants and facilities are employed to increase instructional effectiveness; improve the cleanness, orderliness and safety of facilities; reduce the operational cost and life cycle cost of a building; extend the useful life of a building; increase efficiency and effectiveness of the staff and students; improve building appearance; and use data collection and analyses for decision making. Oviawe and Uwameiye (2010) posited that the level of inadequacy of instructional materials in technical institutions is alarming and that the few available materials in those institutions are abused and mismanaged. An effective index for evaluating standards and quality in TVET is the availability, condition and proper utilization of educational facilities for learning. This situation calls for an appropriate facilities maintenance approach that will utilize material resources for the benefit of learners, TVET institutions and the world of work.

Providing Adequate Facilities: Inadequate facility for TVET is as good as not implementing the curriculum to achieve the desired objectives of the institution and hence effective teaching and learning to prepare the learner, for the world of work and become self- reliant becomes a mirage. In Olaitan (1998) maintained that 
the general atmosphere and lack of facilities has a direct impact on the quality of education learners get. Where there is inadequate facility, instructors will be ill-equipped to perform their duties well hence the quality of learning will be low. It is therefore important to provide adequate facilities for effective teaching and learning. Some of the avenues to providing adequate facilities TVET among others are from:

Government: Federal, state and Local government should provide adequate funds to purchase and equip the schools. There should be special budget for such.

Parent/Teachers Association: They can also make contributions to provide adequate facilities for the schools.

Old Boys/Girls Association: They can be called upon to assist schools in the area of providing adequate facilities. They would love to give back to their former school.

Corporate Organizations: They can be contacted to assist as their corporate social responsibility in the environment where they carry out their businesses.

Industries: They can be approached to not only partner with TVET schools for practical attachment for students but can also be made to assist in providing such facilities to the schools. The effective running of a workshop/laboratory entails some activities fundamental for the smooth maintenance of materials, equipment and personnel involved in the use of the workshop. These activities according to Akinyemi (2013) are: inventory and record; and maintenance services. Inventory and record: the effectiveness of administrative procedures is dependent on the kinds and system of inventory control and records kept. These are administrative activities carried out in all TVET workshops/laboratories. The record of equipment's, tools and supplies should be accurately kept by all school teachers. In addition, adequate records kept will assist teachers in carrying out their duties and it will prove also as a way to ascertain what is on ground as against the records. The teacher can better account properly to the school authorities when the need arises. In aiding management of resources, taking and keeping an inventory of materials and equipment keeps the teacher conscious of the tools that are lost, broken, or out for repairs, and the supplies that are lost or needed (Inyiagu, 2014). Maintenance services: this must not be neglected since it helps to keep tools and equipment in good working state always. The reasons for maintaining tools and equipment in first class condition are to: (i) promote a high degree of efficiency; (ii) maintain safe working conditions; and (iii) keep cost of operations low and prolong the life of equipment (Inyiagu, 2014).

\section{Maintenance of Facilities}

According to Nwachukwu (2012) maintenance of school plant facilities are generally not taken seriously and attitude towards maintenance has not been impressive as it is said that in Nigeria, people lack maintenance culture. This is so because when new buildings are constructed most of the time and the relevant authorities take over, basically no attention is given to maintaining the buildings and nearly no mind is paid to maintaining such a building and this is usually not factored into planning process. A number of school buildings over 50 years old and have never been renovated or modified despite the changes over the years in the educational system. However, Adesina (2010) opined that educational facilities in Nigerian TVET institutions are neglected. Maintaining facilities is a concern in every level of the educational system which ranges from primary education to the university level. A number of these, facility architecture are obsolete and hence has a limited contribution to education. Maintenance of new buildings, modernizing and renovating of old buildings need significant commitment and expertise of material and human resources.

Most weather conditions are not favorable to certain building materials, equipment and machines coupled with poor maintenance culture commonly are responsible for the deterioration and aging of school buildings, equipment and grounds. Students, teachers and school authorities who regularly make use of school facilities do not have the requisite knowledge in planning the maintenance of facilities, which leads to failure to integrate facility maintenance into the school management. The maintenance of such facilities must be therefore an integral part of the overall management of the school. The issue of maintaining facilities has not been adequately addressed at various levels of the educational system and the only alternative when issues 
such as break down is to repair them, whereas prevention they say, is better than cure. Facility maintenance involves: (i) providing adequate facility for learning and teaching therefore should be included in the plan to maintain facilities; (ii) providing clean and safe environment for learning and teaching. There are basically three types of maintenance program called (a) preventive, (b) predictive maintenance and (c) routine, emergency repairs.

Preventive Maintenance: This is done to prevent school facilities breaking down and ensure the performance of the facility is optimal. It involves the use of computers of soft-ware to estimate the failure of equipment using user demand, age and performance measures. However, preventive maintenance is more appropriate as the facilities are kept from unwanted breakdown hence every school manager must need not forget that prevention as they say is better than cure.

Routine Maintenance: Is carried out periodically creating a kind of roaster as deem necessary by the school managers. Facilities may be serviced monthly, quarterly or even annually depending on the agreed schedule.

Emergency Repairs: Is very common in the management of school facilities in societies where maintenance culture is not well established and this takes place when a facility breaks down and urgent measures or step shad to be taken to remedy the situation.

Factors Affecting School Plant Maintenance: The factors affecting the effective maintenance of school plants in TVET institutions in Nigeria include:

Lack Good Leadership: School plant require good leadership for its management to be effectively carried out and be more concerned in ensuring the facilities are properly and correctly used by the students and staff for the purpose for which they were manufactured. Hence top management in schools, either in primary, secondary or university, play an important role in maintaining the school plant.

Lack of Effective Monitoring of the Users of School Plant: Creating a team to monitor educational systems to ascertain if the school plant and individuals using it write reports on their findings, will ensure the school plant lasts long and value is derived from its use. Left unattended to, they will become desolate and unusable for educative purposes.

Lack of School Maintenance Culture: In Ezeji (1998) stated that school plant should be maintained to keep the equipment, building and site in as pristine a condition as possible, with the aim of increasing its durability and life span. School authorities need to randomly check regularly to discover any unforeseen factor that can adversely affect learning and teaching effectiveness in relation to the facility required for it. However, in some institutions, where they have department on works, the staff's attitude is lackadaisical when school plant is in bad condition. If the information on bad school plant is acted on timely, the operations of the institution will run smoothly which will impact learning and teaching effectiveness.

Lack of Adequate Funds: The lack of funds available to effects repairs or regular maintenance of the facilities is also another factor affecting the conditions of the facilities. The resources are not just there to effects the repairs even when the attention has been passed higher up the chain of authority.

Lack of Adequate Security in Schools: Vandalizing school facilities is another limiting factor that needs to be investigated. Students and teachers should be educated on the benefits of maintaining school facilities and to careful, this will ensure they cherish and destroy school plant.

Lack of Maintenance Knowledge and Interest: According to, several person, who occupy management positions in schools lack the requisite knowledge and are not interested in maintaining school facilities. A few with the requisite knowledge fail to practically use it in maintaining facilities. Managing school facilities require inter-mixture of experts in diverse areas so that school facilities can function effectively for a long time. 
Essential Considerations in Facility Planning and Maintenance for TVET Institutions in Nigeria: In planning for the establishment of a new or expanding and maintenance of an already existing TVET plants and facilities needs careful consideration of several factors and consultation of several sources which according to Inyiagu (2014) involves the following seven basic steps sequentially arranged: Preliminary studies to determine the need for and scope of the program should be carried out; Proper location of the workshop/laboratory within the school building is desired; Determination of standards for sizes and shapes of shops, laboratories and other rooms within the facility; Allocation of spatial areas within the individual rooms for bench and machine work, assembly, storage, finishing, planning; Inclusion of physical utilities peculiar to such facilities as lighting, ventilation, power and plumbing; Selection of training equipment functional to the program; and Evaluation of the plan through studies of related material and the assistance of professional resource personnel. The principles for planning for and maintenance of TVET facilities and equipment according to cited in Nwachukwu (2012) are: the school shop should be arranged in a manner, which permits the teacher to teach efficiently, and the student to learn effectively; the workshop should be so arranged so that it is a safe place to work for both the teacher and the student; and the school shop should be arranged so that it presents a pleasing and artistic appearance.

\section{Conclusion and Suggestions}

Functional and adequate school plant facilities in the teaching and learning process is the first step towards the realization of educational objectives in technical vocational education and training institutions hence, it cannot be compromised or neglected. It will be noted that the appearance of the school plant both outside and inside has a cumulative effect on the public attitudes towards a school system. Even though the buildings are old, and located on sites that fall below standards, it is generally regarded is an asset to the community and an expression of educational accomplishment when it is attractive. With adequate facilities teachers' productivity will be high, learning will become motivating and interesting, and students' acquisition of skills towards self-reliance and gainful employment will become more significant. The maintenance of such facilities must be therefore an integral part of the overall management of the school. The actualization of the goals and objectives of TVET require the provision, maximum utilization, appropriate management and maintenance of the school plant facilities. It is only when equipment and facilities are continuously maintained in excellent working condition and sound educational program may be offered. Based on the relevance of school plant facilities as discussed in this paper, the following suggestions are made:

- TVET personnel in institutions of learning should be given regular training in maintenance and management of facilities.

- TVET equipment and training environment must be replica to that of the world of work where products of TVET are expected to fit in upon graduation.

- Since TVET tools, equipment and facilities are cost intensive, government at all levels should make adequate funds available for the smooth running and maintenance of its tools, equipment and other facilities.

\section{References}

Adesina, V. S. (2010). Enhancing capacity utilization of industrial resources. Journal of Industrial Education, $4(3), 60-65$.

Akinyemi, D. E. (2013). Industrial education shop planning guide. Lagos: Packet Nig. Ltd.

Aloga, A. 0. (2014). School Plant Administration: The Challenges and Transformation in Learning and Teaching in Development Centers. (A case study of secondary school in Nigeria). Retrieved on $5^{\text {th }}$ July, 2017 from alogaautin@gmail.com.

Audu, R., Kamin, Y. B. \& Balash, F. (2013). Provision of workshop tools and equipment.

Enyekit, E. O. \& Enyenili, S. (2007). Projecting Nigeria into the End of the First Quarter (25) years of the 21st Century in Vocational and Technical Education. African Journal of Education and Research Development, 1(1), 2-8.

Ezeji, S. C. O. A. (1998). Facilities planning. Unpublished lecture notes. University of Nigeria, Nsukka

Federal Republic of Nigeria. (2013). National Policy on Education. Lagos: NERDC Press.

Inyiagu, E. E. (2014). Essential considerations for improving management of facilities Technical Vocational Education and Training institutions in Nigeria. Nigeria vocational association journal, 19(2), 231-237. 
Khan, Z. (2016). 12 major components of school plant. Retrieved on 10 th December, 2017 from yuourarticulelibrary.com

Knerzevich, S. J. (1975). Curriculum and the School Plant. New York: Harper and Row.

Macleans, F. \& Wilson, D. (2009). International handbook of education for the changing world of work: Bridging Academic and Vocational Learning. Dordrecht: Spring Science w and Business Media.

Nwachukwu, E. H. (2012). Managing multiple activities in industrial education. Ibadan: Spotlight Publishing Co.

Olaitan, S. O. (1998). Vocational education and national development: Constraints and strategies for improvement. In: A.E. Ojo \& F. C. Fashonyim (eds). Manpower development and utilization in Nigeria: Problems and prospects. Lagos: Universal press.

Uwameiye, R. \& Oviawe, J. I. (2010). Availability of human and material resources for teaching block laying and concrete works in technical colleges in Edo state. Ebonyi Technology and Vocational Education Journal, 1(1), 37-47.

UNESCO and ILO Recommendations. (2007). Technical vocational education and training for the $21^{\text {st }}$ century. Paris: UNESCO and ILO publications

Uzodimma, G. B. (1996). Managing the occupational education workshop. Onitsha: Prakken Books Ltd. 